Revised Draft

September 20, 2005

Comments Solicited

\title{
THE CHANGING NATURE OF THE FACULTY AND FACULTY EMPLOYMENT PRACTICES
}

$$
\text { by }
$$

\section{Ronald G. Ehrenberg*}

(Prepared for the TIAA-CREF Institute Conference on "The New Balancing Act in Higher Education”, New York NY, November 3-5, 2005)

*Irving M. Ives Professor of Industrial and Labor Relations and Economics at Cornell University and Director of the Cornell Higher Education Research Institute (CHERI). CHERI is supported by the Andrew W. Mellon Foundation, the Atlantic Philanthropies (USA) Inc. and the TIAA-CREF Institute and I am grateful to them for their support. However, the views expressed here are solely my own. 


\section{Introduction}

The nature of faculty employment practices at American colleges and universities is changing rapidly. So too is the gender, racial and ethnic composition of American faculty members. These changes, along with the growing importance and costs of scientific research, the increased commercialization of faculty research, the elimination of mandatory retirement for tenured faculty members and the growing costs of retiree health insurance, the growing salary differentials across universities and academic fields within an university, and the growth of collective bargaining for tenured and tenure-track faculty and graduate assistants at public universities and now adjuncts at private universities, have put enormous stresses on our nation's academic institutions and their leaders. The discussion that follows explains why.

\section{The Growth in Contingent Faculty}

During the last three decades, there has been a significant growth in the share of faculty members at American colleges and universities that are employed in part-time or full-time non tenure-track positions. ${ }^{1}$ In 1975 , full-time tenured and tenure-track faculty members were $56.8 \%$ of the faculty nationwide at America's 2-year and 4-year colleges and universities, while full-time non tenure-track faculty and part-time faculty were 13.0\% and 30.2\%, respectively. By 2003, full-time tenured and tenure-track faculty had fallen to $35.1 \%$, while the latter two categories had risen to $18.7 \%$ and $46.3 \%$, respectively. ${ }^{2}$ This substitution of contingent or contract faculty for tenured and tenuretrack faculty is at least partially due to the growing financial pressures faced by public and private higher education institutions, partially due to the lower costs of hiring non

\footnotetext{
${ }^{1}$ Anderson (2002), Baldwin and Chronister (2001), Conley, Lesley and Zimbler (2002), Ehrenberg and Zhang (2005a).

${ }^{2}$ Curtis (2005)
} 
tenure-track faculty members, and partially due to the increased flexibility that hiring such faculty members gives academic institutions in the face of uncertain economic times and the end of mandatory retirement for tenure track faculty members (that took place in 1994). ${ }^{3}$

To give the reader a sense of the role that contingent faculty play at major American universities, table 1 presents information on the distribution of faculty types at a number of selective private universities during academic year 2003-2004. That year, less than $25 \%$ of the faculty members were contingent faculty at Cornell and Rochester, however, $50 \%$ or more of the faculty members were contingent faculty at Boston College, Browne, NYU, and Tufts. At the latter set of institutions, many of these contingent faculty members were part-time faculty.

Of course part-time faculty members teach fewer classes than full-time faculty members and it is interesting to ask what percentage of undergraduate credit hours at an academic institution are generated by contingent faculty. Such information is not readily available for private institutions, but data from the State University of New York system, which I have cited elsewhere, show that between the fall of 1992 and the fall of 2001, the percentage of undergraduate credit hours taught by faculty members with tenure or on tenure-tracks at the four university centers fell from $81 \%$ to $58.4 \%$, a decrease of over 22 percentage points. ${ }^{4}$ Moreover, between the Fall of 1994 and the Fall of 2004, the number of full-time faculty members at the four university centers (including those not on tenure tracks) fell by 251 from 4,348 to 4,097, while the number of part-time faculty members

\footnotetext{
${ }^{3}$ Ehrenberg and Zhang (2005a), Monks (2004)

${ }^{4}$ Ehrenberg and Klaff (2003), table 2. The four university centers in the SUNY system are Albany, Binghamton, Buffalo and Stony Brook.
} 
increased by 616 from 1283 to $1899 .{ }^{5}$ Given that the number of full-time equivalent students at the university centers increased from 62,179 to 72,571 during the period, it is clear that instructional workload was being shifted onto the backs of part-time faculty. ${ }^{6}$

There are a number of reasons that the public and university leaders should be concerned about such shifts in who is teaching our undergraduate students. First, while it would be delightful if we could substitute lower paid part-time and full-time non tenuretrack faculty for more costly tenure-track faculty and not influence the quality of education that undergraduate students receive, a growing body of research suggests that on balance there is a cost to students of this type of substitution. For example, Liang Zhang and I analyzed institutional level panel data from the College Board and other sources and found that increases in a 4-year institution's usage of part-time or full-time non tenure-track faculty is associated, other factors held constant, with a decline in its students' graduation rates. ${ }^{7}$ Similarly, using a unique individual record data set for all students enrolled in 4-year public higher education institutions in Ohio, Eric Bettinger and Bridget Terry Long found that students with "adjunct heavy” course schedules in their first year of study are less likely to persist at the institution into the second year, other factors held constant. ${ }^{8}$

Why might such findings occur? After all many non tenure-track faculty are dedicated teachers and, without any research expectations placed on them, can devote themselves fully to teaching. However, full-time non tenure-track faculty teaching loads are often higher than tenure-track faculty teaching loads, which may leave the former

\footnotetext{
${ }^{5}$ Office of Institutional Research and Analysis (2005)

${ }^{6}$ A number of the papers in Ehrenberg (forthcoming) present similar data on the growing use of part-time and full-time non tenure-track faculty in other states public universities.

${ }^{7}$ Ehrenberg and Zhang (2005b)

${ }^{8}$ Bettinger and Long (forthcoming)
} 
less, rather than more, time for individual students. Part-time faculty members, especially in urban areas, often must find employment at multiple institutions to make ends meet, and have little time (and often no place) to meet students outside of class. The full-time tenured and tenure-track faculty members, who may be more connected to their institution and more up to date on their department's curriculum, may also be better prepared to advise students.

The term contingent faculty is probably a misnomer because many full-time non tenure track faculty are in fact quasi-permanent employees, who have multi year contracts and for whom there often is a career path. For example, at my own university lecturers typically have multi-year contracts and, after a period of service, can be promoted to the rank of senior lecturer. A number of research universities, including Duke, Emory, and NYU are experimenting with creating a more prestigious "professor of practice” career path in which faculty members who specialize in teaching are paid salaries much closer to the average tenure-track salaries in their fields than lecturers are paid, receive the same benefits as their tenure-track colleagues (but often not sabbaticals), and are employed on renewable long-term contracts. ${ }^{9}$

Whether such a two-tier system, with lower (but better than now) paid teaching faculty, who have higher teaching loads than other faculty, will be a direction in which more universities will move is unclear. If they do so, the financial savings to universities from substituting away from tenure-track faculty will be smaller than it currently is. To the extent that the majority of the undergraduate teaching at an institution is done by non tenure-track faculty without research responsibilities, undergraduate students will also miss out on one of the major reasons for coming to a research university - being exposed

\footnotetext{
${ }^{9}$ Fogg (2004)
} 
to great researchers and the research process. Indeed, if we view one of the important roles of research universities as encouraging undergraduate students to consider undertaking advanced study in the disciplines, the failure to involve our undergraduate students in research will reduce the flow of American college graduates into $\mathrm{PhD}$ programs. $^{10}$

Indeed, the fraction of $\mathrm{PhD}$ degrees granted in the United States that go to American citizens and permanent residents has been declining for decades. In 1973, less than $10 \%$ of PhDs went to temporary residents of the United States; by 2003 this had risen to $26 \%$. Virtually all of the increase in the total number of PhDs produced during the 30 year period has come from the growth in foreign PhD students; the number of American students receiving PhDs had remained essentially flat in spite of large increases in the number of American college graduates. Moreover, in key science and engineering fields, the percentage of PhD degrees now granted to foreign students is much higher. In 2003, 38\% of all the PhDs in the physical sciences and 55\% of all the PhDs in engineering granted by American colleges and universities went to foreign students. ${ }^{11}$

Part of the decline in the interest in American students in pursuing $\mathrm{PhDs}$ is undoubtedly due to the reduction in the likelihood that new PhDs can obtain tenure-track positions, because of the growing use of contingent faculty positions. Increasing time-todegrees, coupled with the increasing need for multiple multi-year relatively low paid postdoctoral appointments in many science and engineering fields before tenure-track positions can be obtained, have also increased $\mathrm{PhD}$ students' discontent and led to the

\footnotetext{
${ }^{10}$ Ehrenberg (2005a)

11 Thomas Hoffer et. al. (2004), table 11
} 
growing unionization of graduate students in public higher education. ${ }^{12}$ So a new generation of PhDs will have very different attitudes towards collective bargaining than the older faculty who they are replacing.

The lower salaries and benefits that contingent faculty receive has also led to a growing movement to have contingent faculty covered by collective bargaining agreements. Although tenure-track faculty at private colleges and universities are precluded from organizing under the NLRB's Yeshiva decision, in July 2002, NYU became the first major private university in the nation in which an adjunct-only union was certified as a bargaining agent by the NLRB. ${ }^{13}$ While the university has publicly painted the pay increases, health benefits, pension benefits and job security arrangements that were negotiated in the contract as a win-win situation, collective bargaining contracts constrain the freedom of university administrators to manage their institutions as they see fit.

\section{Who Will be the Faculty of the Future}

In 1973, 18\% of all PhDs granted in the United States were females; by 2003 this percentage had risen to $45.3 \%$. The female share of PhDs has risen in all fields, even in traditionally male dominated fields, such as the physical sciences and engineering. ${ }^{14}$ However, in spite of the growing numbers of new female $\mathrm{PhDs}$, females are under represented on the faculty of most major American research universities, especially in the science and engineering fields, and are more likely to be found on the faculty of liberal arts colleges. For example, in my own field, economics, females represented $15.0 \%$ of the

\footnotetext{
${ }^{12}$ In 2005, collective bargaining for graduate assistants at private universities was effectively at least temporarily precluded by the NLRB in its New York University decision

${ }^{13}$ Smallwood (2002)

${ }^{14}$ Hoffer et. al. (2004), table 7
} 
tenured and tenure-track faculty at doctorate granting institutions, but $27.7 \%$ at liberal arts colleges. $^{15}$

The under representation of female faculty at research universities may be due to a number of factors. It may represent female PhDs’ preferences for teaching rather than research. It may represent perceptions by females that research universities are not hospitable environments for them. It may represent perceptions by females that there is more gender discrimination in hiring and promotion decisions at research universities, or the actuality of more gender discrimination at research universities. Finally, it may represent the difficulty faced by female faculty members in combining families and careers at research universities.

A recent study suggests that family issues are an important component of the explanation. ${ }^{16}$ This study analyzed data from the Survey of Doctorate Recipients; a large biennial national longitudinal study that follows the careers of about 160,000 $\mathrm{PhD}$ recipients. It focused on the career histories of individuals who received $\mathrm{PhDs}$ between 1978 and 1984, started their careers at universities, and were still working in academia 12 to 14 years later. It found that men who had children within 5 years of receiving their PhDs were 38\% more likely to have received tenure than their female counterparts who had children within 5 years of receiving their PhDs. While $70 \%$ of the male faculty members who received tenure were married with children, only $44 \%$ of female faculty members who received tenure were married with children; moreover female faculty members with tenure were twice as likely as male faculty members with tenure to be single. It also found that only one in three women who takes a university job before

\footnotetext{
${ }^{15}$ Newsletter of the Committee on the Status of Women in the Economics Profession (2005), tables 2 and 4

${ }^{16}$ Mason and Goulden (2004)
} 
having children ever became a mother during the period and that women who were married at the time they began their first academic jobs were more likely than their male counterparts to get divorced or separated.

Not surprisingly then, in effort to increase the attractiveness to female PhDs of faculty careers at research universities, a number of major universities have launched efforts to make their institutions more "family friendly". One notable example is the University of California system which, with the help of the Alfred P. Sloan Foundation, has developed a set of policies that it calls "The UC Family Friendly Edge" ${ }^{17}$ These policies include

1. A flexible part-time option for tenured and tenure-faculty that can be used for up to 5 years as life-course needs arise

2. A guarantee to make high quality child care available

3. A commitment to assist new faculty members with spousal/partner employment issues

4. A postdoctoral fellowship program to encourage PhDs who have taken time off from their careers for family reasons to reenter academia

5. Educating faculty committees that family-related gaps in resumes (such as those due to time off for child birth and or the postponing of tenure clocks for the same reason) should be discounted in hiring and tenure decisions

6. Establishing summer camps and school-break child care for faculty children

7. Establishing emergency backup child care programs and

8. Establishing benefits for faculty who want to adopt children

\footnotetext{
${ }^{17}$ http://ucfamilyedgeberkeley.edu
} 
Key aspects of the UC policy include marketing it to potential new hires and building mechanism to ensure that all faculty members at the university, including department chairs fully understand the policies. Other universities are involved in similar efforts. For example, Princeton has made it mandatory that all faculty members of either gender that have a new child (through birth or adoption) automatically get a year extension on their tenure clocks, as a way of eliminating the concern of some female faculty members that they would be stigmatized in their departments if they had to request such leave. Some institutions have adopted, or are considering adopting, a wider range of policies including providing funding for child care when faculty members are presenting papers at conferences, developing permanent part-time tenure-track positions, or addressing other family-related issues, such as the serious illness of a faculty member or a faculty member's family, elder care issues and support for faculty facing such problems. Their hope is that by making their workplace more family friendly, universities will find it easier to attract and retain female faculty.

Their desire to attract and retain female faculty, especially in science and engineering fields, derives at least partially from the belief that by providing same gender role models more female students will major in science and engineering, go on to advanced study in these fields, and once enrolled in advanced study, persist to earning their degrees. Evidence to support these beliefs is in fact mixed. ${ }^{18}$ Even if these hypotheses are correct, there is still the question of from where the resources will come to support the creation of

\footnotetext{
${ }^{18}$ Canes and Rosen (1995) found no evidence that the gender composition of departments at three selective academic institutions influenced female undergraduates choice of majors, while Rash and Bailey (2002) and Ashworth and Evans(2001) found that it did. More recently Bettinger and Long (2005) found that having a female faculty member in a class increased the likelihood that female college students would take additional classes in mathematics and geology, but they found no such relationship in engineering, physics and computer science. Finally, Neumark and Gardecki (1998) found that female graduate students in economics were more likely to complete their degrees when they had female mentors.
} 
these family friendly policies. It is not an accident that the first research universities to develop them are our nation's wealthiest private and public institutions. It will be more difficult, for example, for universities that currently don't have enough resources to provide meaningful travel funds for their faculty, to even dream about being able to provide funding for child care for faculty attending meetings.

In contrast to the large increase in the fraction of PhDs being awarded to American citizens and permanent residents that go to women, the fraction of PhDs being awarded to students from historically under represented groups is still quite modest, especially in key science and engineering fields. For example, the percentages of American citizen doctoral degrees in 2003 in the physical science, engineering and the life science fields that went to members of under represented groups (African Americans, Hispanic Americans and American Indians) were 6.7\%, 8.5\% and $8.1 \%$ in the three fields, respectively. ${ }^{19}$ The small numbers of members of these groups in faculty positions in American universities is largely a pipeline problem and America's great research universities need to devote more effort to increase the flow of their undergraduate students from under represented groups into $\mathrm{PhD}$ programs. ${ }^{20}$

\section{Increasing Importance and Cost of Scientific Research}

Advances in modern biology, advanced materials and information sciences, which together promise (and are beginning to deliver) improvements in human welfare, have led to the growing importance of scientific and engineering research at universities. In spite of generous increases in external funding, increasingly the cost of research is being borne by academic institutions themselves and the start-up cost packages necessary to attract

\footnotetext{
${ }^{19}$ Hoffer et. al. (2004), table 8

${ }^{20}$ Ehrenberg (2004a)
} 
top young scientists and engineers now are in the $\$ 500,000$ range; the start-up cost packages for senior scientist often are well over $\$ 1,000,000 .^{21}$ Public universities, more than private universities, indicate that they fund these start-up cost packages at least partially through salary savings earned by keeping faculty positions for scientists and engineers vacant until the salary savings generated provide the resources needed for the start-up package; this contributes to the growing use of contingent faculty for instructional purposes at public universities. $^{22}$

The growth in the demand for scientific research has led to a growth in the demand for scientific researchers that exceed the growth in demand for faculty to teach science at universities. As a result, we have seen a tremendous expansion in the usage of research assistants, postdoctoral fellows, research associates and senior research associates at universities. At many universities individuals employed in these positions can not be principle investigators on research grants and some universities are now experimenting with professorial titles (e.g. research professor) to retain top non teaching faculty and to allow them to pursue independent research grants. Individuals in these positions are typically not on tenure-tracks so all of the issues that arise in terms of improving compensation and job security for contingent teaching faculty also arise here. The compensation of people in these positions is often very similar to the compensation of research faculty in medical colleges; the faculty members are expected to generate research funding to cover most, or all, of their salaries. How they are treated when their grant funding expires is a major issue in defining these types of appointment.

\footnotetext{
${ }^{21}$ Ehrenberg, Rizzo and Jakubson (forthcoming)

22 Ehrenberg, Rizzo and Condie (2003)
} 
The growth of the scientific enterprise in the U.S. has been fueled by the growing number of foreign PhD students and foreign postdoctoral researchers in the United States. Changes in U.S. policy since 9/11, coupled with the growth of graduate education and the research enterprises in foreign countries, make it unclear whether the U.S. can continue to count on attracting the same numbers of these talented foreign $\mathrm{PhD}$ students and postdoctoral researchers to our country in the years ahead. ${ }^{23}$ This means that steps must be taken to increase the supply of American students going into PhD study and academic careers and to accomplish this will inevitably require increases in faculty compensation levels, which American colleges and universities will have to bear.

\section{Faculty Compensation Differentials}

Growing faculty salary differential across institutions, across fields within each institution and across faculty members in the same department, as well as growing compensation differences between faculty members who receive income from commercializing their research findings and those who do not, are a fact of life in American higher education. These trends create serious problems for leaders of our universities.

The financial problems faced by public higher education institutions have led to the average salaries of faculty at public doctoral universities falling substantially relative to the average faculty salary of faculty at private doctoral universities over the last three decades; this makes it harder for the public universities to recruit and retain top faculty. ${ }^{24}$ During periods of relatively modest faculty salary increases in public higher education, efforts by public universities to retain top faculty who have received job offers from other

\footnotetext{
${ }^{23}$ Ehrenberg (2005b)

${ }^{24}$ Ehrenberg (2003)
} 
academic institutions contributes to growing salary differentials within departments. This creates strains on academic institutions; if the only way to generate salary increases is to search for an outside offer, faculty commitment to the institution goes down, and faculty members' sense of shared purpose is also diminished.

This problem is exacerbated by a widening of salary differentials across fields, which reflects the growing importance of external nonacademic markets in faculty salary determination in higher education. Data from an annual salary survey by field for a set of doctoral-granting institutions (primarily publics) that has been conducted by the Office of Institutional Research and Information Management at Oklahoma State University since 1974 illustrates the magnitude of this problem. In 2001-2002, the average salaries of new assistant professors in Business Management, Computer and Information Sciences, Economics, Engineering, and Law and Legal Studies were, respectively, 213.5, 169.7, 150.5, 147.1 and 168.2 percent higher than the average salaries of assistant professors in English. ${ }^{25}$ Faculty salary differentials by field are smaller at the full professor level and also vary across universities. ${ }^{26}$ When the quality of a the faculty in field is higher, as measured by the National Research Council ratings of the field at an institution, other factors held constant, average full professor salaries in the field are higher relative to average full professor salaries in English at the institution. ${ }^{27}$ Wide and growing faculty salary differentials across fields also contribute to the loss of collegiality at the university.

In fields that are growing in importance and that have substantial nonacademic employment opportunities, sometimes the increase in the starting salary for new assistant professors that occurs between two years, which is determined by market forces at the

\footnotetext{
${ }^{25}$ Ehrenberg (2004b), table D

${ }^{26}$ Ehrenberg (2004b), tables C and D

${ }^{27}$ Ehrenberg, McGraw and Mrdjenovic (forthcoming)
} 
national level, is larger than the amount that the resources of an institution permit the average salary for continuing assistant professors to increase. This leads to a form of salary inversion, with new faculty members earning more than faculty members with a number of years experience at the institution. Such salary inversion creates incentives for experienced faculty members to look for other employment and also has a negative impact upon faculty morale.

So too do efforts to commercialize scientists research findings. The financial rewards from patenting research findings that lead to licensing agreements or the creation of start-up companies is potentially very large for both the university and the faculty member making a discovery. ${ }^{28}$ Researchers are just beginning to sort out, how these relationships affect academic culture and the relationships between faculty members in departments in which some faculty members earn large incomes from commercialization of their research findings, but others earn none. ${ }^{29}$

\section{Mandatory Retirement and Health Insurance Issues}

The abolition of mandatory retirement for tenured faculty, effective in 1994, has fundamental implications for academia. Studies suggest that abolition of mandatory retirement has had only a small impact on faculty members' retirement rate, with the largest impact coming at our nation's private research universities. ${ }^{30}$ However, these studies were undertaken before the dramatic decline in the stock market in 2000; the values of the retirement accounts of many faculty members covered by defined contribution pension plans are barely at the same levels in 2005 that they were five years

\footnotetext{
${ }^{28}$ However, Ehrenberg, Rizzo and Jakubson (forthcoming) find that very few universities are actually making money on their commercialization activities.

${ }^{29}$ Stephan and Ehrenberg (forthcoming)

${ }^{30}$ Ashenfelter and Card (2002), Ehrenberg, Matier and Fontanella (2000)
} 
earlier. As a result, many senior faculty members' expectations about their retirement incomes are lower now than they were five years ago and this may induce some to postpone retirement.

Dramatic increases in health insurance costs are also leading some academic institutions to modify or reduce the generosity of their health insurance coverage for retirees; a trend that is occurring among American employers. ${ }^{31}$ Unlike pension benefits, which cannot be legally reduced once a faculty member retires, retiree health insurance programs can be altered after retirement (by negotiations if the health benefits are provided through collective bargaining contracts, unilaterally by the university otherwise). Moreover a large number of faculty are employed at academic institutions that do not provide any funding for retiree health costs; a national survey undertaken by the American Association of University Professors in 2000 found only 58\% of academic institutions contributed to the costs of their faculty retirees' health insurance. ${ }^{32}$ Uncertainty about who will pay for their health costs in retirement may well cause many faculty members to postpone their plans for retirement.

The postponement of retirement decision by faculty, as well as the uncertainty of when faculty will retire, imposes costs on academic institutions; new faculty hiring is slowed down, and it is difficult to plan for faculty replacements. Academic institutions have altered their retirement programs to provide incentives for faculty to retire (buy outs and the like) and provided other incentives for faculty to retire, such as opportunities for

\footnotetext{
${ }^{31}$ Moon (2005)

${ }^{32}$ Ehrenberg (2001)
} 
phased retirement and for retired faculty to teach on a part-time basis. ${ }^{33}$ Only recently, however, have they begun to confront the issue of retiree health insurance.

One innovative program has been developed by the Emeriti Consortium for Retirement Health Solutions, a nonprofit company that grew out of a project funded by the Andrew W. Mellon Foundation. ${ }^{34}$ The program combines tax advantages for academic employers and faculty members to contribute to a personal retiree health care account for a faculty member using before-tax dollars. These funds are invested in selected mutual funds whose investment returns are not subject to personal income taxes. When a faculty member retires, he or she can make tax-free withdrawals from his or her account to cover the costs of Medicare supplemental insurance premiums, and out of pocket medical expenses, including prescription-drug costs not covered by Medicare. ${ }^{35}$

As of August 2005, 29 academic institutions, primarily private liberal arts colleges belonged to the consortium and were making contributions to these accounts for their older faculty members; many other institutions have expressed interest in participating in the program. Some participating institutions have their own retiree health insurance plans, but others do not. So another aspect of the program is the establishment of several health insurance options that provide supplementary health insurance coverage designed to supplement Medicare coverage. These programs were designed with faculty members' needs in mind and, by being open to faculty around the nation, can be offered at relatively low costs to individuals.

Recently public attention has been drawn to the difficulty that nationwide public and private employers in many industries are having in financing defined benefit pension

\footnotetext{
${ }^{33}$ Ehrenberg (2001)

${ }^{34}$ Pulley (2005) (Also see the program's web site, www.emertihealth.org for details)

${ }^{35}$ Fronstin and Yakobski (2005) provide a broader discussion of such retiree medical account programs.
} 
plans. In large part these difficulties arise from low rates of stock market returns at the turn of the $21^{\text {st }}$ century and, in some industries such as automotives, an increasing ratio of retirees to active employees. As a result a number of employers are abandoning their defined benefit plans (which can be done prior to participants retiring) and instead substituting defined contribution retirement accounts in an effort both to cap their liabilities for retirees' pension benefits and to increase the predictability of what their liabilities for future retirement benefits will be each year.

The Emeriti Consortium for Retirement Health Solutions program may lead to a similar thing occurring with respect to faculty retiree health care coverage. Faculty at institutions that previously did not fund any retiree health insurance benefits will clearly be better off with such a program and an institution's adopting it may lead its faculty members to retire earlier than otherwise would be the case. On the other hand, academic institutions that currently contribute to faculty retirees' health insurance costs may see participating in the Emeriti Consortium program as a way of limiting their future liabilities for retiree health care costs and they may substitute this defined contribution program for their own current retiree health insurance plan. Such a substitution might increase older faculty members' uncertainty about their future health care costs and induce them to postpone their retirement dates. Academic administrators will have to think long and hard in the years ahead about the issue of health coverage for retired faculty members. 


\section{References}

Orley Ashenfelter and David Card, "Did the Elimination of Mandatory Retirement Affect Faculty Retirement?”, American Economic Review 92 (September 2002): 957-980

Eugene L. Anderson, The New Professoriate: Characteristics, Contributions and Compensation (Washington DC: American Council on Education, 2002)

Bettinger and Long

John L. Ashworth and J. Lynn Evans, "Modeling Student Subject Choice at Secondary and Tertiary Level: A Cross-Section Study”, Journal of Economic Education 32 (Fall 2001): 311-322

Roger G. Baldwin and Jay L. Chronister, Teaching Without Tenure: Policies and Practices for a New Era (Baltimore MD: Johns Hopkins Press, 2001)

Eric P. Bettinger and Bridget Terry Long”, “Do Faculty Serve as Role Models? The Impact of Instructor Gender on Female Students”, American Economic Association Papers and Proceedings 95 (May 2005):

Eric P. Bettinger and Bridget Terry Long, "Help or Hinder? Adjunct Professors and Student Outcomes” in Ronald G. Ehrenberg ed. What's Happening to Public Higher Education?” (Westport CT: ACE Praeger Series on Higher Education, forthcoming)

Brandice Canes and Harvey Rosen, “Following in Her Footsteps? Faculty Gender Composition and Women's Choice of College Majors”, Industrial and Labor Relations Review 48 (April 1995): 486-504 
John Curtis, “Trends in Faculty Status, 1975-2003”, (Washington DC: American Association of University Professors, May 26, 2005) (available on the web at http://www/aaup.org/research/FacstatTrends.htm )

Valerie M. Conley, David W. Lesley and Linda J. Zimbler, Part-Time Instructional Faculty and Staff: Who They Are, What They Do, and What They Think (Washington DC: U.S. Department of Education, 2004)

Ronald G. Ehrenberg, “Career’s End: A Survey of Faculty Retirement Policies”, Academe 87 (July/August 2001): 24-29

Ronald G. Ehrenberg, "Studying Ourselves: The Academic Labor Market”, Journal of Labor Economics 21 (April 2003): 221-235

Ronald G. Ehrenberg, “Two Different Worlds - Discussion”, American Economic Association Papers and Proceedings 94 (May 2004): (2004a)

Ronald G. Ehrenberg, “Don’t Blame Faculty for High Tuition: The Annual Report on the Economic Status of the Profession, 2003-2004”, Academe 90 (March/April 2004): 20-31 (2004b)

Ronald G. Ehrenberg, "Involving Undergraduate Students in Research to Encourage Them to Undertake PhD Study in Economics”, American Economic Association Papers and Proceedings 95 (May 2005): (2005a)

Ronald G. Ehrenberg, “Graduate Education, Innovation and the Federal Responsibility”, Communicator 38 (July 2005): 1-8 (2005b)

Ronald G. Ehrenberg Ed. What's Happening to Public Higher Education? (Westport CT: ACE/Praeger Series on Higher Education, forthcoming) 
Ronald G. Ehrenberg and Daniel B. Klaff, "Changes in Faculty Composition Within the State University of New York System: 1985-2001”, Cornell Higher Education Research Institute Working Paper No. 38 (Ithaca NY: Cornell Higher Education Research Institute, August 2003) (available at www.ilr.cornell.edu/cheri )

Ronald G. Ehrenberg, Michael Matier, and Peter Fontanella, “Cornell University Confronts the End of Mandatory Retirement” in Robert Clark and Bret Hammond eds. To Retire or Not Retire: Retirement Policy and Practice in Higher Education (Philadelphia PA: University of Pennsylvania Press, 2000)

Ronald G. Ehrenberg, Marquise McGraw and Jesenka Mrdjenovic, "Why Do Field Differentials in Average Faculty Salaries Vary Across Universities?”, Economics of Education Review (forthcoming)

Ronald G. Ehrenberg, Michael J. Rizzo and George H. Jakubson, "Who Bears the Growing Cost of Science at Universities?” in Paula E. Stephan and Ronald G. Ehrenberg eds. Science and the University (Madison WI: University of Wisconsin Press, forthcoming)

Ronald G. Ehrenberg, Michael J. Rizzo and Scott S. Condie, "Start-Up Costs in American Research Universities”, Cornell Higher Education Research Institute Working Paper No. 33 (Ithaca NY, Cornell Higher Education Research Institute, March 2003) (available at www.ilr.cornell.edu/cheri )

Ronald G. Ehrenberg and Liang Zhang, "The Changing Nature of Faculty Employment” in Robert Clark and Jennifer Ma eds. Recruitment, Retention and Retirement in Higher Education: Building and Managing the Faculty of the Future (Northampton MA: Edward Elgar, 2005): 32-52 (2005a) 
Ronald G. Ehrenberg and Liang Zhang, "Do Tenured and Tenure-Track Faculty Matter?” Journal of Human Resources 40 (Summer 2005): 647-659 (2005a)

Piper Fogg, “For These Professors, 'Practice’ is Perfect”, Chronicle of Higher Education 50 (April 16, 2004): A12

Paul Fronstin and Paul Yakoboski, Options and Alternatives to Fund Retiree Health Care Expenditures (New York, NY: TIAA-CREF Institute, July 2005)

Thomas Hoffer et. al. Doctorate Recipients from United States Universities: Summary Report 2003 (Chicago IL: NORC at the University of Chicago, 2004)

Mary Ann Mason and Mark Goulden, “Do Babies Matter (Part II)”, Academe 90 (November/December 2004): 11-15

James W. Monks, “The Relative Earnings of Contingent Faculty in Higher Education”, Cornell Higher Education Research Institute Working Paper No. 59 (Ithaca NY, Cornell Higher Education Research Institute, December 2004) (available at www.ilr.cornell.edu/cheri )

Marilyn Moon, Retiree Health Care: Individuals Picking Up Bigger Tab (New York NY: TIAA-CREF Institute, July 2005)

David Neumark and Rosella Gardecki, “Women Helping Women? Role Model and Mentoring Effects on Female PhD Students in Economics”, Journal of Human Resources 33 (Winter 1998): 220-246

Newsletter of the Committee on the Status of Women in the Economics Profession (Ithaca NY: Committee on the Status of Women in the Economics Profession, Winter 2005) (available at www.cswep.org ) 
Office of Institutional Research and Analysis, Trends in SUNY Employees, Fall 1994 Through Fall 2004 (Albany NY: State University of New York System, May 2005) (available at www.sysadm.suny.edu/irdocs/employees/employees.htm )

John L. Pulley, “College Group Devises a New Way to Pay for Retirees’ HealthCare Costs”, Chronicle of Higher Education 51 (June 3, 2005): A21

Kevin N. Rask and Elizabeth M. Bailey, “Are Faculty Role Models? Evidence from Major Choice in an Undergraduate Institution”, Journal of Economic Education 33 (Spring 2002): 99-124

Scott Smallwood, “UAW Will Represent Part-Time Faculty Members at New York U.”, Chronicle of Higher Education 48 (July 19, 2002): A10

Paula E. Stephan and Ronald G. Ehrenberg eds. Science and the University (Madison WI: University of Wisconsin Press, forthcoming) 
Table 1

Numbers and Percentages of Faculty in Different Categories at Selected Private Universities in 2003- 2004

\begin{tabular}{|l|l|l|l|l|}
\hline Institution & $\begin{array}{l}\text { Total } \\
\text { Faculty } \\
\text { Size }\end{array}$ & $\begin{array}{l}\text { Tenured and } \\
\text { Tenure Track } \\
\text { (percentage) }\end{array}$ & $\begin{array}{l}\text { Full-time Non } \\
\text { Tenure Track } \\
\text { (percentage) }\end{array}$ & $\begin{array}{l}\text { Part-Time Non } \\
\text { Tenure Track } \\
\text { (percentage) }\end{array}$ \\
\hline Boston College & 1089 & $548(50 \%)$ & $131(12 \%)$ & $410(38 \%)$ \\
\hline Brown & 902 & $468(52 \%)$ & $285(32 \%)$ & $149(17 \%)$ \\
\hline Cornell & 1940 & $1477(76 \%)$ & $348(18 \%)$ & $115(6 \%)$ \\
\hline NYU & 5083 & $1292(25 \%)$ & $630(12 \%)$ & $3162(62 \%)$ \\
\hline Rochester & 591 & $465(79 \%)$ & $100(17 \%)$ & $26(4 \%)$ \\
\hline Tufts & 1036 & $359(35 \%)$ & $275(27 \%)$ & $402(39 \%)$ \\
\hline
\end{tabular}

${ }^{\mathrm{a}}$ Excluding medical college faculty Source: Report from the ad hoc Committee on Contract Faculty to the Provost and the Faculty Senate, Brandeis University (March 17, 2005), appendix table A-2 (available on the web at www.brandeis.edu/departments/provost/contract_faculty_comm.html ). The data come from the 2003 IPEDs EAP Survey (available at http://nces.ed.gov/ipeds ). The data are as reported by the institutions. Employees who do not have faculty status are excluded, as are graduate assistants. 